\title{
Efficacy of Immune System Challenges with Tiny Enemy COVID-19
}

\author{
Huda S. Jassim* \\ Department of Microbiology, College of Veterinary Medicine, University of Baghdad, Iraq
}

\section{Review Article}

\begin{abstract}
The objective of this review article was to discuss the interaction between virus effectiveness and host immune system challenges on the innate and adaptive on how the immune system able to defend against COVID-19 viral infections. Genetically, the COVID-19 is a virus that has genetic material coated by lipid with a crown of protein. The virus that causes COVID-19 is called severe acute respiratory syndrome coronavirus two (SARS-COV-2) and was first detected in humans last December 2019. Primarily, the COVID-19 virus spreads with droplets of saliva or nose discharge when an infected person sneezes or coughs. Most people with a healthy immune system those infected with the COVID-19 virus showed mild to moderate respiratory illness and recovered without needing special treatment. The aged people those had medical problems such as cardiovascular disease, diabetes, chronic respiratory disease, and cancer are most likely to develop serious illness. In-conclusion: Little is known about viral clearance, but regulation innate immune response associated with development of adaptive immunity neutralizing antibodies, memory $\mathrm{T}$ and $\mathrm{B}$ lymphocytes in convalescent patients raises hope for active immunization.
\end{abstract}

Keywords: COVID-19, Convalescent Plasma, Angiotensin-converting enzyme 2, Immune responses, B.C.G. vaccine

\section{Introduction}

Primary immune response to respiratory virus

\section{infection}

Coronaviruses (COVs) are the largest group of known positive-sense RNA viruses having an extensive range of natural hosts, newly evolved Coronaviruses have posed a global threat to public health. The immune response is essential to control and eliminate COV infections, however, immune responses may result in immunopathology and

\footnotetext{
*Correspondence: Huda.sadoon@yahoo.com,

Department of Microbiology, College of Veterinary Medicine, University of Baghdad. Received: 19 May 2020, Accepted: 25 June 2020, Published: 28 June 2020.

This article is an open access article under the terms and conditions of the Creative Commons Attribution License (CC BY 04).

https://crerativecommons.org/licenses/by/4.0).
}

DOI: $\underline{\text { https://doi.org/10.30539/ijvm.v44i1.940 }}$ impaired the pulmonary gas exchange that persistence with development the inflammation in the lungs (1). Most studies addressing T-cell responses to respiratory virus infections (2). Start of the immune response against pathogens invading begins with direct infection of airway epithelium. Following initial infection and lung resident respiratory dendritic cells (rDCs) that acquired the invading antigens or pathogen from epithelial cells infected and become activated. Process antigen and migrate to drain to the mediastinal and cervical lymph nodes (DLN). However, once the infection in the DLNsandr DCs present, the processed antigen in form of MHC-peptide complex to naive circulating $\mathrm{T}$ cells. Following engagement of the T cell receptor (TCR) with peptide-MHC complex and additional co-stimulation signals, $\mathrm{T}$ cells become activated, proliferate strongly, and migrate to the site of infection (Figure 1) (3). At the site of infection, 
activated virus specific effector $\mathrm{T}$ cells secrete antiviral cytokines as interferon gamma (IFN- $\gamma$ ), tumor necrosis factor alpha (TNF- $\alpha$ ) and interleukintwo, chemokine-XC-ligand 9CXCL-9, chemokine10 and 11 and cytotoxic substances (perforin and agranzyme B) (4). Effector cytokines as IFN- $\gamma$ directly inhibit replication viral and enhance presentation antigen (5). The chemokines produced by activated $\mathrm{T}$ cells recruit too more innate and adaptive cells to control pathogen burden. Cytotoxic molecules such granzyme B directly kill epithelial infected cells and help in eliminate the pathogen (6). SARS-COV-2 is new to humanity so it needs several days for antiviral T-cell to expand and antibodies to be produced, no protective immunological memory.
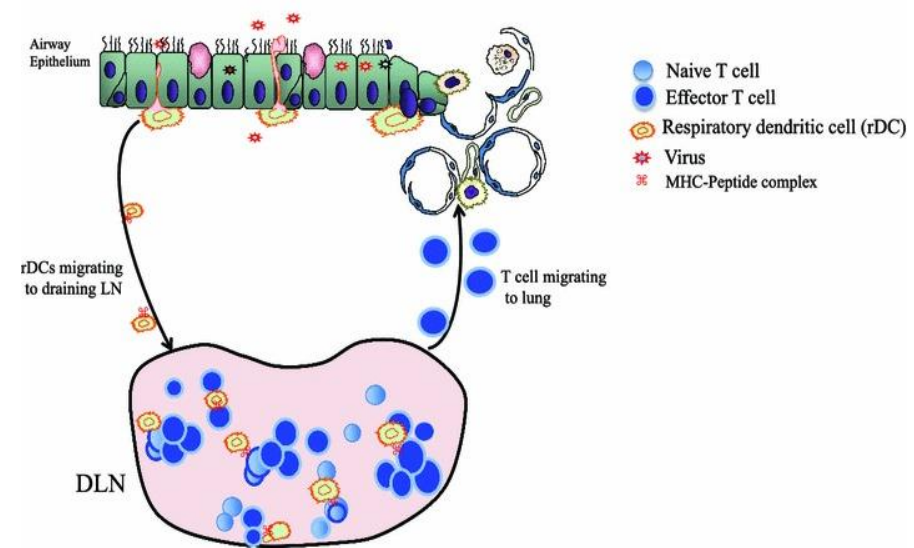

Figure 1. $T$ cell response with respiratory virus infection (3)

The virus replicates before immune cells detected it and alarm raise. Antibody proteins that can adhere to the virus spike proteins and prevent attachment to target cells are called neutralizing antibodies (7), these antibodies are other types of coronaviruses (SARS; MERS) may continue from one to three years.

However, the COVID-19 is a new virus, don't yet know long-lasting antibody responses to Sars-COV2 would be generated. In COVID-19, the potential mechanisms may lead to lymphocyte deficiency. The virus might directly infected lymphocytes which resulting lymphocyte damage. Lymphocytes express the coronavirus receptor Angiotensin-converting enzyme 2 (ACE2) and may be a direct target of viruses (8). They might directly destroy lymphatic organs, and the direct damage of novel coronavirus virus to organs such as thymus and spleen. Inflammatory cytokines perhaps leading to lymphocyte apoptosis, TNF- $\alpha$, interleukin -6 , and other pro-inflammatory cytokines could lead lymphocytes deficiency (9). Inhibition of lymphocytes by metabolic molecules might produce by metabolic disorders such as hyperlacticacademia (10).

Infection Coronavirus regardless of the varies types of corona which is primarily attacked by immune cells as the mast cells (MCs) that located in the submucosa of the respiratory ways and in the nasal cavity and represent a barrier of protection against microbes. Viral activate MCs release early inflammatory chemical granules including histamine and protease; while late activation stimuli the generation of pro-inflammatory interleukin-1family members including IL-1, IL-6 and IL-33 (11).

\section{The BCG Vaccine and Corona}

The BCG vaccine was discovered in the 1800 s by observation that milkmaids did not develop the tuberculosis. That vaccine is named when its inventors, Dr. Albert Calmette and Dr. Camille Guerin developed it in early 1900 from bacteria mycobacterium bovis is a form of tuberculosis that infected cattle (12).

The COVID-19 incidence cases in countries where the vaccine BCG is used with countries where it is not used observed that countries routinely used the vaccine in newborn had more less cases reported of COVID-19 till now, the differences in national demographics and disease burden, test rates for COVID-19 virus infections, and the stage pandemic in each of country would be considered (13).

The vaccine apparently trains the immunity system to recognize and respond to a variety of infections, include viruses, parasites and bacteria (12). Based on BCG capacity to reduce the incidence of respiratory tract infections in children with exert antiviral effects in experimental lab. Model sand to reduce viremia in an experimental human model of viral infection, that suppose is the BCG vaccination induces partial 
protection against susceptibility to and/or severity of COVID-19 infection (14).

\section{Treatment with Convalescent Plasma in COVID-} 19

The using convalescent plasma for the treatment of viral diseases is not new, it has already been tried in the early century of $20^{\text {th }}(15)$, when there was no effective antiviral agent, the therapy plasma has been attempted. Plasma therapy was contributed to severe acute respiratory syndrome (SARS), Influenza, Virus Ebola and Middle East respiratory syndrome (MERS-CoV), and it seems to have got effective results (16-18).

Targets of COVID-19 treatment divided into two units. First, it is focus on the virus by destroying the virus itself. However, destroying the virus itself is a concept of disinfection and is some dangerous for individuals in apply. As a therapeutic drug, the inhibit replication of RNA-dependent RNA polymerases Remdesiviror drugs inhibit protease as lopinavir//ritonavir) (19). The second target is Angiotensin converting enzyme 2 (ACE2) as a gatekeeper and viruses receptor of enter human cells which raising the intracellular $\mathrm{pH}$, glycosylation of ACE2 that might prevented to block the virus corona entry such as chloroquine (20) or can prevent from binding to ACE2 in advance by sticking to the virus protein spike (21).

A plasma therapy itself has complications important, examples are transfusion related acute lung injury (TRALI), anaphylaxis (22) and these complications should be in concerned. There is also the possibility side effects that have been raised recently, it is the antibody dependent enhancement entry (ADE), neutralizing antibodies, once bound to the spike protein of the virus that might cause a conformational change of the spike and consequently that could trigger the paradoxical result of better entry into human cells through the Fc Ig receptor $(23,24)$.Yet this side effect has not been realized, but should be kept in memory in future of treatment plasma and development vaccine. Convalescent plasma therapy gives us a lot hope, but there are challenges to overcome.
In conclusion, little is known about viral clearance, but regulation of innate immune response associated with development of adaptive immunity neutralizing antibodies, memory $\mathrm{T}$ and $\mathrm{B}$ lymphocytes in convalescent patients raises hope for active immunization.

\section{References}

1. Li G, Fan Y, Lai Y, Han T, Li Z, Zhou P, et al. Coronavirus infections and immune responses. $\mathrm{J}$ Med Virol. 2020;92(4):424-432.

2. Bouvier NM, Lowen AC. Animal Models for Influenza Virus Pathogenesis and Transmission. Viruses. 2010; 2(8):1530-1563.

3. Rudragouda C, Jincun Z, Stanley P. T cellmediated immune response to respiratory coronaviruses Immunol Res. 2014; 59(1): 118128.

4. Wherry EJ, Ahmed R. Memory CD8 T-cell differentiation during viral infection. J Virol. 2004; 78(11):5535-45.

5. Saha B, Jyothi Prasanna S, Chandrasekar B, Nandi D. Gene modulation and immunoregulatory roles of interferon gamma. Cytokine. 2010;50(1):1-14.

6. Román E, Miller E, Harmsen A, Wiley J, Von Andrian UH, Huston G. et al. CD4 effector T cell subsets in the response to influenza: heterogeneity, migration, and function. $\mathrm{J}$ Exp Med. 2002;196(7):957-68.

7. Judith A, Owe AO, Punt J, Stranford SHA, Jones PP. Innate immunity. In Kuby immunology, $7^{\text {th }}$ ed., W. H. Freeman and Company, U.S.A. 2013; Chap57, Immunology: p.152-160.

8. $\mathrm{Xu} \mathrm{H}$. High expression of ACE2 receptor of 2019$\mathrm{nCoV}$ on the epithelial cells of oral mucosa. Int J. Oral. Sci. 2020; 12 (8).

9. Liao YC, Liang WG, Chen FW, Hsu JH, Yang JJ, Chang MS. IL-19 induces production of IL-6 and TNF- $\alpha$ and results in cell apoptosis through TNF$\alpha$. The Journal of Immunology. 2002; 15;169(8): 4288-97.

10.

11. Fischer K, Hoffmann P, Voelkl S, Meidenbauer $\mathrm{N}$, Ammer $\mathrm{J}$, Edinger $\mathrm{M}$, et al. Inhibitory effect of tumor cell-derived lactic acid 
on human T cells. Blood. 2007: May 1; 109(9): 3812-9.

Kritas SK, Ronconi G,Caraffa A, Gallenga CE,

Ross R, Conti P. Mast cells contribute to coronavirus-induced inflammation: new antiinflammatory strategy. Biol Regul Homeost Agents. 2020; 34(1). doi: 10.23812/20-Editorial-Kritas.

Can an Old Vaccine Stop the New Coronavirus? By Roni Caryn Rabin

https://www.nytimes.com/2020/04/03/health/corona virus-bcg-vaccine.html.

12. WHO. Bacille Calmette-Guérin (BCG) vaccination and COVID-19 (2020).

13. Reducing Health Care Workers Absenteeism in Covid-19 Pandemic Through BCG Vaccine (BCG-CORONA).

https://clinicaltrials.gov/ct2/show/NCT0432844 1,2020 .

14. Mair-Jenkins J, Saavedra-Campos M, Baillie JK, Cleary P, Khaw FM, Lim WS, et al. The effectiveness of convalescent plasma and hyperimmune immunoglobulin for the treatment of severe acute respiratory infections of viral etiology: a systematic review and exploratory meta-analysis. J Infect Dis. 2015;211(1):80-90.

15. WHO. Use of convalescent whole blood or plasma collected from patients recovered from Ebola virus disease for transfusion, as an empirical treatment during outbreaks. 2020.

16. Shanmugaraj B, Siriwattananon K, Wangkanont K, Phoolcharoen W. Perspectives on monoclonal antibody therapy as potential therapeutic intervention for Coronavirus disease-19 (COVID-19). Asian Pac J Allergy Immunol. 2020;38(1):10-18.

17. Hung IF, To KK, Lee CK, Lee KL, Chan K, Yan WW, et al. Convalescent plasma treatment reduced mortality in patients with severe pandemic influenza A (H1N1) (2009). Virus infection. Clin Infect Dis. 2011;52(4):447-456.

18. $\mathrm{Lu} \mathrm{H}$. Drug treatment options for the 2019new coronavirus (2019-nCoV). Biosci Trends. 2020;14(1): 69-71.
19. Kim JY, Ko JH, Kim Y, Kim YJ, Kim JM, Chung YS, et al. Viral load kinetics of SARSCOV-2 infection in first two patients in Korea. $\mathrm{J}$ Korean Med Sci. 2020;35(7):p.86.

20. Tian X, Li C, Huang A, Xia S, Lu S, Shi Z, et al. Potent binding of 2019 novel coronavirus spike protein by a SARS coronavirus-specific human monoclonal antibody. Emerging microbes and infections. 2020; 1;9(1):382-5.

21. Pandey S, Vyas GN. Adverse effects of plasma transfusion. Transfusion. 2012; 52 Supp11:65S-79S.

22. Wan Y, Shang J, Sun S, Tai W, Chen J, Geng $\mathrm{Q}$, et al. Molecular mechanism for antibodydependent enhancement of coronavirus entry. Journal of virology. 2020; 14(5) p.94.

23. Wang SF, Tseng SP, Yen CH, Yang JY, Tsao $\mathrm{CH}$, Shen $\mathrm{CW}$, et al. Antibody-dependent SARS coronavirus infection is mediated by antibodies against spike proteins. Biochem Biophys Res Commun. 2014;451(2):208-214. 


\section{فعالية تحديات الجهاز نظام المناعة مع العدو الصغي2OVID-19 \\ هدى سعدون جاسم}

فرع الأحياء المجهريه , كلية الطب البيطري ,جامعة بغداد

الخلاصة

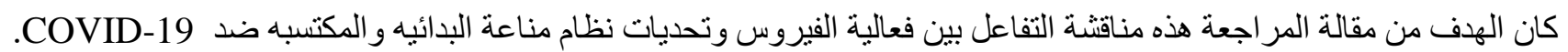

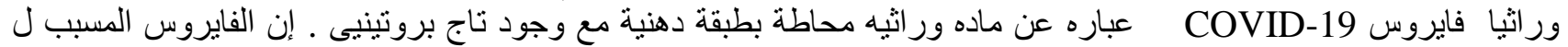

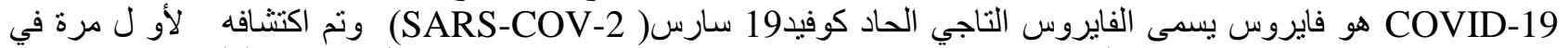

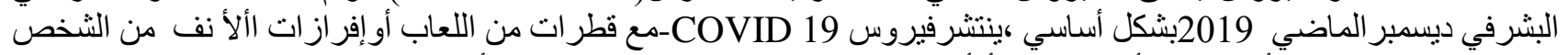

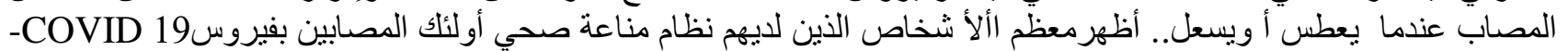

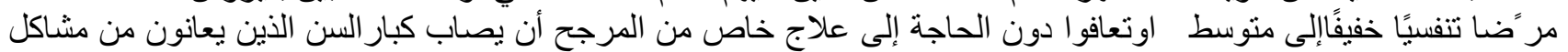

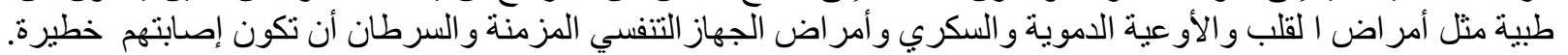

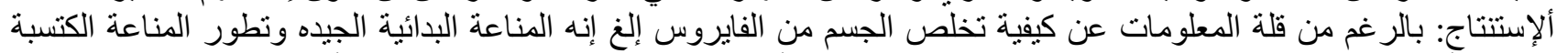

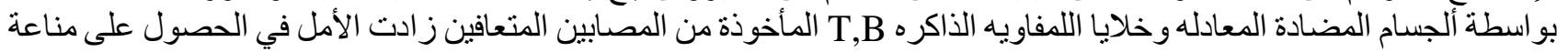
مكتسبة فعالة. الكلمات المفتاحيه : فايروس , المناعه , بلازما النقاهة, سارس ,كوفيد19 